\title{
Výzkum kvality počáteční čtenářské gramotnosti žáků 1. ročníků základních škol
}

\author{
Research quality initial reading literacy of pupils on the 1st class at elementary schools \\ Marie Švrčková
}

\begin{abstract}
Abstrakt: Př́spěvek prezentuje problematiku výzkumu kvality počáteční čtenářské gramotnosti žáků 1. ročníků základních škol. Výzkumný záměr se pokouší o zavedení chybějící konceptualizace mezi pojmy čtenářská gramotnost a kompetence. Počáteční čtenářská gramotnost je vymezována jako komplex několika, vzájemně se prolínajících, rovin. Cílem výzkumu bylo zjistit a popsat kvalitu počáteční čtenářské gramotnosti žáků 1. ročníků základních škol. Výzkum prezentované oblasti je deskripcí současného stavu výuky počátečního čtení v 1 . ročnících vybraných škol. Výzkumný vzorek žáků byl záměrným kvótním výběrem. Z hlediska použité metodologie mělo realizované empirické šetření povahu smíšeného designu výzkumu. Výsledky výzkumu pojmenovávají rozdílnost v kvalitě počáteční čtenářské gramotnosti zkoumaného vzorku žáků a poukazují na odlišnost metodických přístupů výuky počátečního čtení v 1. ročníku základní školy.
\end{abstract}

Klíčová slova: gramotnost, počáteční čtenářská gramotnost, kompetence, čtenářská kompetence, výzkum PIRLS, výzkum PISA, metody výuky počátečního čtení

\begin{abstract}
The paper presents problems of quality the initial reading literacy of 1st class pupils at elementary schools from the research point of view. The research project tries to introduction of absence conceptualization among literacy concepts and competences. Initial reading literacy is specified as a complex of several levels which blends together. The research objective was to determine and describing the initial quality of pupils' literacy of $1 \mathrm{st}$ class at elementary schools. Research of this presented area is a description of contemporary state of teaching initial reading in 1st class at selected schools. The research sample of pupils, parents and teachers was purposeful quota selection. From viewpoint of research methodology we used mixed method design. The results of this research identify of difference in quality of the initial reading literacy skills of pupils sample and point out methodological approaches diversity in teaching of initial reading in 1st class at primary school.
\end{abstract}

Keywords: literacy, initial reading literacy, competencies, reading comptence, research PIRLS, research PISA, the methods of the teachings the initial reading

\section{1 Úvod}

Problematika kvality čtenářské gramotnosti žáků základní školy je stále více diskutována především v kontextu s výsledky úspěšnosti českých žáků $v$ mezinárodních šetřeních této oblasti, a to v projektech PIRLS (Progress in International Reading Literacy Study) asociace IEA a PISA (Programme for International Student Assessment) organizace OECD. Tyto výzkumy zjišt'ují čtenářskou gramotnost žáků 4. a 5. ročníků základní školy a žáků 9. ročníků. V našem systému základního vzdělávání však 5. a 9. ročník školní docházky považujeme za 
výstupní prvního a druhého vzdělávací období. Proto lze na výsledky uvedených šetření nahlížet jako na „ukazatele efektivity“ základního vzdělávání. Otevřenou otázkou zůstává, pro koho jsou výsledky těchto šetřeni určeny a jaká je validita interpretace výsledku pro školní vzdèláváni??

V této souvislosti považujeme za důležité upozornit na skutečnost, že rozvoj čtenářské gramotnosti začíná mnohem dřive než ve 4. ročníku základní školy. Čtenářská gramotnost je velmi složitý komplex úzce související s rozvojem psychických procesů dítěte/žáka, s rozvojem myšlení, poslechu a vyjadřování. Chceme li se podílet se na zvýšení kvality základního vzdělávání, měli bychom se problematikou čtenářské gramotnosti zabývat od počátku zahájení školní docházky žáka. Jsme zastánci názoru, že je potřebné zabývat se touto problematikou od vstupu dítěte do mateřské školy. V těchto úsecích vzdělávání však shledáváme jistou absenci výzkumů této oblasti.

\section{2 Úskalí výzkumů čtenářské gramotnosti}

V kontextu se zmíněnými mezinárodními výzkumy bychom se měli zamyslet se nad možnými úskalími těchto výzkumů. Již v úvodu bylo naznačeno zamyšlení se nad validitou interpretací výsledků uvedených šetření pro školní vzdělávání. Zpochybňování validity zmíněných výzkumů „souvisí snejednoznačným vymezením pojmů i vzájemných vztahi̊ mezi gramotností, poznatky, kompetencemi, kontextem, apod." (Štech, 2011, s. 129). Pedagogická teorie i praxe postrádá určitou konceptualizaci mezi zmíněnými pojmy, které bývají často užívány s nepřesným (př́ípadně obecným) vymezením.

Podle Barré de-Miniac (2003) užitečnost pojmu gramotnost spočívá v heuristické inspiraci pro výzkumy směřující k zvýšení didaktické efektivnosti výuky. „, Gramotnost jako empirický pojem poskytuje výzkumu v didaktice určitou svobodu prozkoumávat různé cesty. To nás ovšem nezbavuje povinnosti vytvářet koncepty (teoretické pojmy) schopné doložit osvojování gramotnosti, forem jejího používáni i predáváni apod. Musíme dávat velký pozor a nedopustit, aby slovo a zpưsob jakým se využivá k měreni kompetencí, sloužily jako alibi pro chybějicí konceptualizaci" (Barré de-Miniac, 2003 in Štech, 2011, s. 130).

$\mathrm{K}$ rizikům můžeme také řadit př́liš velký důraz na výsledky realizovaných mezinárodních šetření. Nelze si nepovšimnout, že došlo k proměně vztahu mezi výzkumem „efektivní školy“ a praxí založenou na „důkazech“, jež může vést až k tzv. „reduktivnímu“ pojetí vzdělávání ohrožující kvalitu didaktických procesů na školách.

\section{Vymezení počáteční čtenářské gramotnosti}

Jedním ze záměrů šetření této oblasti bylo pokusit se o vytvoření konceptualizace mezi uvedenými pojmy a specifikovat pojem počáteční čtenářská gramotnost v kontextu s pojmem kompetence ${ }^{1}$. Zároveň bylo dbáno, aby námi pojaté koncepční uchopení odpovídalo podmínkám systému vzdělávání ČR, bylo využitelné v pedagogické praxi a v didaktice této oblasti. ${ }^{2} \mathrm{~S}$ existujícím množstvím př́vlastků k pojmu gramotnost se jeho užívání stává komplikovanější. Existuje řada modelů, stupňů a druhů gramotnosti. Proto se jeví jako potřebné důkladně promyšlené použití tohoto pojmu.

\footnotetext{
${ }^{1}$ Vzniklá konceptualizace mezi uvedenými pojmy je v př́spěvku prezentovaná pouze okrajově.

2 Projektem vzniklá konceptualizace je také užívána ve výzkumném záměru OPVK „Rozvoj čtenářských kompetencí v prostředí inkluzivní školy"/CZ.1.07/1.1.00/08.0061/, PdF Univerzity Karlovy v Praze, na němž se spoluřešitelsky podílíme.
} 
Z didaktického hlediska nechápeme osvojování si čtení na počátku vzdělávání pouze jako rozvoj základní dovednosti na úrovni dekódování znaků. Pod označením počáteční čtenářská gramotnost míníme , komplex schopností a dovedností souvisejicich s osvojením si dovednosti čist a s utvářrením kladného postoje ke čtení. Čteni se stává je nejen prostředkem ziskáváni informací, ale také prostředkem ziskáni nových emocionálních prožitkü "(Švrčková 2011, s. 49). Počáteční čtenářskou gramotnost tvoří několik, vzájemně se prolínajících rovin, z nichž každá má svůj specifický význam v celostním rozvoji žáka. Těmito rovinami jsou technika čtení a psaní, vztah ke čtení, porozumění, vyvozování, metakognice, sdílení a rovina aplikace. ${ }^{3} \mathrm{~V}$ základu se sice opíráme o definici autorů VÚP Praha a členů programu „Č́tením a psaním ke kritickému myšlení“ (Košt'álová et al., 2010), avšak naše vymezení je pouze myšlenkově shodné $\mathrm{s}$ touto definicí. Pro empirické šetření byla vytvořena vlastní charakteristika jednotlivých rovin odpovídající specifikám žákovi ml. školního věku a požadavkům primárního vzdělávání.

Součástí výzkumného záměru byla obsahová analýza dostupných dokumentů a zdrojů věnující se problematice kompetencí, jíž jsme specifikovali čtenářskou kompetenci (viz obr. 1). Čtenářskou kompetenci chápeme jako komplex dílčích složek, které tvoří čtenářská dovednost, kompetence číst $\mathrm{s}$ porozuměním a kompetence číst texty literární. Je to „způsobilost čtenáre umožňující mu porozumět, používat a reflektovat psané texty, aby dosáhl vlastnich cílů, rozširíil své vědomosti a potenciál a účastnil se společenského života " (Garbe, 2007, s. 116).

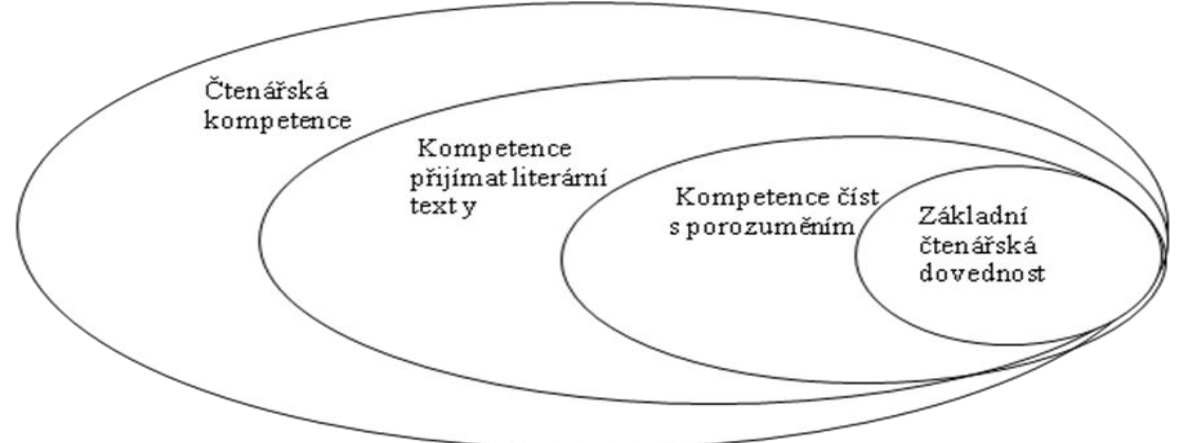

Obrázek 1. Vyjádření vtahu mezi dílčími složkami čtenářské kompetence (Švrčková, 2011 s. 71).

Ve výzkumném záměru pak čtenářkou kompetenci žáka ml. školního věku pojímáme jako výše uvedený komplex odpovídající tomuto stupni psychického vývoje umožňující užívat všech druhů textů v různých individuálních i sociálních kontextech.

\section{Design empirického šetření}

Hlavním cílem šetření bylo zjistit a popsat úroveň počáteční čtenářské gramotnosti žáků 1 . ročníku základní školy (tj. kvalitu sledovaných rovin). K upřesnění výzkumného záměru byly stanoveny dílčí výzkumné otázky, jimiž jsme zjišt'ovali, zdali existuje rozdíl v kvalitě počáteční čtenářské gramotnosti žáků 1. ročníků vyučovaných odlišnými metodami výuky počátečního čtení. Ve kterých rovinách počáteční čtenářské gramotnosti se tyto rozdíly projevují a jaký je posun žáků 1 . ročníků komparovaných skupin v kvalitě počáteční čtenářské gramotnosti během školního roku.

\footnotetext{
${ }^{3}$ Každá z rovin byla vymezena specifickými kritérii a ukazateli, dle kterých byly výsledky vyhodnoceny.
} 
Výzkumný vzorek byl záměrným kvótním výběrem, v němž byly upřednostněny dva kontrolní znaky, věk žáků (6 a 7 let) a metoda výuky čtení učitele. Výběrový soubor tvořili žáci, záměrně vybraných tř́íd 1. ročníku základních škol Moravskoslezského kraje (Ostravska) ve školním r. 2010/2011. Realizace šetření proběhla dvěma měřeními. První měření bylo uskutečněno v lednu 2011, druhé na přelomu dubna/května 2011.

Výzkum navazoval na výsledky pilotáže (květen 2009) s cílem zjistit a popsat stav metodiky výuky čtení v 1. ročnících základní školy ČR, v době po zavedení Rámcového vzdělávacího programu základního vzdělávání. Pilotáží bylo specifikováno kritérium kvality výběru zkoumaného vzorku, za něž jsme považovali nejvíce užívanou metodu výuky čtení učitele 1. ročníku základní školy. Získaná data byla vyhodnocena na základě odevzdaných 311 dotazníků učitelů vyučujících v 1. ročnících základních škol ČR. Výsledky pilotáže ukázaly, že nejvíce užívanou metodou výuky čtení v 1. ročníku základních škol ČR je metoda analyticko-syntetická (dále jen A-S), v $81 \%$ a metoda genetická, v 11\% zkoumaného vzorku. Použití dalších metod bylo minimální.

Vlastní empirické šetření mělo povahu smíšeného výzkumu. Pro sběr dat jsme použili testovou metodu (tři typy didaktických testů), dotazníkové šetření, zúčastněné pozorování žáka a interview. Získaná data byla zpracována statistickým vyhodnocením a kvalitativním popisem. Vyhodnocení dat bylo pomocí absolutní a relativní četnosti proměnných, aritmetického průměru, dvou výběrového $\mathrm{T}$ - testu (s rovností a nerovností rozptylů), jemuž předcházel Fischerův F-test a dále byla použita popisná analýza. Pro zjištění posunu žáků mezi oběma měřeními byl použit párový T- test.

\section{Vybrané výsledky}

Výsledky šetření byly zpracovávány na základě komparace získaných dat jednotlivých skupin zkoumaného vzorku žáků, nikoli na základě srovnávání „efektivity“ jednotlivých metod výuky čtení. Výsledky jsme chtěli pojmenovat rozdílnosti v kvalitě počáteční čtenářské gramotnosti u žáků zkoumaného vzorku pro následnou didaktickou využitelnost v profesní praxi. Z výsledků šetření vyplývá, že kvalita počáteční čtenářské gramotnosti žáků 1. ročníků vyučovanými odlišnými metodickými přistupy výuky počátečního čtení je rozdílná. Tato rozdílnost byla zjištěna $\mathrm{v}$ kvalitě námi sledovaných rovin počáteční čtenářské gramotnosti. Sledovány byly roviny technika čtení, vztah ke čtení, rovina porozumění, rovina metakognice, rovina vyvozování a rovina aplikace (rovina sdílení pro svou specifičnost nebyla sledována).

Ačkoli výsledky žáků porovnávaných skupin se v jednotlivých měřeních odlišovaly, celkově neúspěšnější byli v obou měřeních žáci 1. ročníků vyučováni metodou genetickou. Při porovnávání průměrných výsledků kvality jednotlivých rovin, byly prokázány také statisticky významné rozdíly, a to ve prospěch žáků vyučovaných metodou genetickou. Také v kvalitě roviny vztahu ke čtení se prokázalo, že celkově kladnější vztah ke čtení měli žáci 1. ročníkủ vyučovaných metodou genetickou. Kladnější vztah ke čtení měli žáci 1. ročníků vyučovaných metodou A-S s inovativními prvky než žáci 1. ročníků vyučovaní metodou A-S s tradičními prvky, tj. větší procentuální část žáků 1. ročníků vyučovaných metodou genetickou a žáků 1 . ročníků vyučovaných A-S s inovativními prvky své odpovědi uváděla na škále kladných odpovědí. Největší individuální rozdíly byly zaznamenány ve čtenářských výkonech jednotlivých žáků 1. ročníků vyučovaných metodou A-S s inovativními prvky. U všech skupin žáků byl mezi oběma měřeními zaznamenán posun ve výsledcích, zlepšení. 


\section{Závěr}

Závěrem bychom chtěli říci, že kvalita počáteční čtenářské gramotnosti žáků 1. ročníků není pouze odrazem rozdílnosti jednotlivých metod výuky počátečního čtení, ale podílí se na ni celá řada faktorů. Jimi jsou především vlastní didaktická práce učitele a individualita žáka. Proto při hodnocení kvality této složky vzdělávání nelze na výsledky žáků nahlížet jako na ukazatele „efektivity“, ale k výsledkům žáků musíme přistupovat velmi ohleduplně. V podmínkách soudobého vzdělávání je výzkumné šetření této oblasti v tomto období vzdělávání a svým koncepčním pojetím ojedinělým počinem. Přínos empirického šetření shledáváme jak v konceptualizaci uvedených pojmů, tak specifikaci počáteční čtenářské gramotnosti a čtenářské kompetence žáků 1. ročníku základní školy. Za významné považujeme vytvoření nástrojů pro měření kvality počáteční čtenářské gramotnosti. Přínos výzkumného šetření vidíme také ve vlastní didaktické využitelnosti výsledků. Výstupy výzkumného šetření budou použity ke zkvalitnění př́pravy budoucích učitelů primárního stupně.

\section{Literatura}

Garbe, Ch. (2008). Lesen, seine bedeutung und förderung. Dostupné z http:// www.npkk.cz/csk/files/SKIP_ctenarstvi_2008.pdf

Gavora, P., \& Zápotočná, O. et al. (2003). Gramotnost'. Vývin a možnosti jej didaktického usmerňovania. Bratislava: UK v Bratislavě.

Koštálová, H., Šafránková, K., Hausenblas, O., \& Šlapal, M. (2010). Čtenářská gramotnost jako vzdèlávaci cíl pro každého žáka. Praha:ČŠI.

Kramplová, I., \& Potužníková, E. (2005). Jak (se) uči číst. Praha: ÚIV.

Štech, V. (2011). PISA - nástroj vzdělávaci politiky nebo výzkumná metoda? Orbis Scholae, 5(1), $123-132$.

Švrčková, M. (2011). Počáteční čtenářská gramotnost a klíčové kompetence (Disertační práce). Praha: PdF UK v Praze.

\section{Kontakt}

Mgr. Marie Švrčková, Ph.D.

Ostravská univerzita v Ostravě

Pedagogická fakulta, Katedra pedagogiky primárního a alternativního vzdělávání

Mlýnská 5, 70103 Ostrava 1

e-mail: marie.svrckova@osu.cz

\section{Bibliografické údaje}

Švrčková, M. (2011). Představy budoucích pedagogů o hodnotách výchovy a vzdělávání. In T. Janík, P. Knecht, \& S. Šebestová (Eds.), Smíšený design v pedagogickém výzkumu: Sborník př́spěvků z 19. výroční konference České asociace pedagogického výzkumu (s. 451-455). Brno: Masarykova univerzita.

Dostupné z: http://www.ped.muni.cz/capv2011/sbornikprispevku/svrckova.pdf doi: 10.5817/PdF.P210-CAPV-2012-76 